\title{
KONDISI KUALITAS AIR SUNGAI CILIWUNG DI WILAYAH DKI JAKARTA DITINJAU DARI PARAMATER ORGANIK, AMONIAK, FOSFAT, DETERJEN DAN BAKTERI COLI
}

\author{
Satmoko Yudo \\ Pusat Teknologi Lingkungan, Badan pengkajian dan Penerapan Teknologi (BPPT) \\ JI. MH. Thamrin No. 8, Jakarta
}

\begin{abstract}
Jakarta city has 13 rivers one of which is Ciliwung river. It flows across the city amid a lot of dense housing, slums and villages. As a result the river is experiencing the most severe pollution compared to other rivers that flow in Jakarta. To find out how much pollution in the Ciliwung river, this paper will discuss several pollutant parameters such as, BOD, COD, ammonia, phosphates, detergent and coli bacteria. Overall, that the concentrations of these parameters continue to increase annually, this causing pollution in the Ciliwung river higher.
\end{abstract}

Keywords : Ciliwung rivers, water pollution from domestic wastewater, river water quality, organic parameters, ammonia, phosphates, detergent and coli bacteria.

\section{PENDAHULUAN}

Sungai sebagai salah satu komponen lingkungan yang memiliki fungsi penting bagi kehidupan manusia termasuk untuk menunjang pembangunan perekonomian. Akan tetapi sebagai akibat adanya peningkatan kegiatan pembangunan di berbagai bidang maka baik secara langsung ataupun tidak langsung akan mempunyai dampak terhadap kerusakan lingkungan termasuk didalamnya pencemaran sungai. Pencemaran sungai umumnya berasal dari limbah domestik maupun limbah non domestik seperti limbah dari perumahan, perkantoran, pabrik dan industri. Oleh karena itu pencemaran air sungai dan lingkungan sekitarnya perlu dikendalikan seiring dengan laju pembangunan agar fungsi sungai dapat dipertahankan kelestariannya.

13 (tiga belas) sistem aliran sungai yang mengalir di wilayah DKI Jakarta sebagian besar berhulu di daerah Jawa Barat dan bermuara di Teluk Jakarta. Dengan demikian sungai di DKI Jakarta merupakan tempat limpahan akhir dari pada buangan-buangan tersebut. Padahal sungai itu sendiri mempunyai banyak fungsi yang sangat penting, antara lain sebagai sumber air baku air minum, perikanan, peternakan, pertanian, dan usaha perkotaan (1).

Kualitas air di wilayah DKI Jakarta sudah sangat mengkhawatirkan, hal ini berdasarkan pemantauan yang dilakukan Badan Pengendalian Lingkungan Hidup Daerah (BPLHD) DKI Jakarta di 13 sungai yang melintasi wilayah Jakarta menunjukkan, baik air sungai maupun air tanah memiliki kandungan pencemar organik dan anorganik tinggi. Akibatnya, air sungai diwilayah DKI Jakarta tidak sesuai lagi dengan baku mutu peruntukkannya yaitu untuk air minum, perikanan, pertanian dan usaha perkotaan lainnya (2).

Diantara 13 sungai yang mengalir di Jakarta, sungai Ciliwung memiliki dampak yang paling luas karena ia mengalir melalui tengah kota Jakarta dan melintasi banyak perkampungan, perumahan padat, dan pemukiman-pemukiman kumuh. Sungai ini juga dianggap sungai yang paling parah mengalami perusakan dan pencemaran limbah domestik dibandingkan sungai-sungai lain yang mengalir di Jakarta (3).

Keterangan di atas menunjukkan bahwa secara umum kondisi perairan di wilayah Jakarta sudah waktunya perlu perhatian yang sangat serius untuk dibenahi pemerintah bersama masyarakat. Usaha pemantauan kualitas air sungai secara berkala perlu terus dilakukan dan usaha-usaha pemerintah bersama masyarakat baik itu usaha penegakan hukum ataupun usaha sosialisasi untuk meningkatkan kualitas lingkungan perairan harus terus dilakukan. Sehingga diharapkan sungai sebagai sumber air bersih untuk kebutuhan hidup manusia yang utama tetap terjaga kualitasnya dan tidak semakin tercemar.

\section{TUJUAN DAN SASARAN}

Tujuan dari tulisan ini adalah melakukan analisa dan evaluasi terhadap kondisi pencemaran air limbah domestik di sepanjang sungai Ciliwung wilayah Jakarta serta memberikan suatu alternatif teknologi yang diharapkan dapat mengurangi beban pencemaran tersebut. 
Sasaran yang akan dicapai adalah memberikan gambaran kondisi pencemaran air limbah domestik di Jakarta dan membantu dalam perencanaan untuk memperbaiki kualitas air yang masuk ke badan sungai di Jakarta.

\section{PENCEMARAN AIR LIMBAH DOMESTIK}

Berdasarkan Peraturan Gubernur Propinsi DKI Jakarta Nomor 112 Tahun 2005 yang dimaksud air limbah domestik adalah air limbah yang berasal dari kegiatan rumah tangga, perumahan, rumah susun, apartemen, perkantoran, rumah dan kantor rumah dan toko, rumah sakit, mall, pasar swalayan, balai pertemuan, hotel, industri, sekolah, baik berupa grey water (air bekas) ataupun black water (air kotor/tinja) (4).

Menurut Lembaga Kajian Ekologi dan Konservasi Lahan Basah, limbah domestik terbagi dalam dua kategori yaitu pertama, air limbah domestik yang berasal dari air cucian seperti sabun, deterjen, minyak dan pestisida. Kedua adalah air limbah yang berasal dari kakus seperti sabun, shampo, tinja dan air seni. ${ }^{(5)}$

Air limbah domestik menghasilkan senyawa organik berupa protein, karbohidrat, lemak dan asam nukleat. Pada musim kemarau saat debit air sungai turun hingga 300\% maka masukan bahan organik kedalam badan air akan mengakibatkan penurunan kualitas air. Beberapa kondisi badan sungai saat musim kemarau antara lain:

1. Badan air memerlukan oksigen ekstra guna mengurai ikatan dalam senyawa organik (dekomposisi), akibatnya akan membuat sungai miskin oksigen, membuat jatah oksigen bagi biota air lainnya berkurang jumlahnya. Pengurangan kadar Oksigen dalam air ini sering mengakibatkan peristiwa ikan mati masal akibat kekurangan Oksigen.

2. Limbah organik mengandung padatan terlarut yang tinggi sehingga menimbulkan kekeruhan dan mengurangi penetrasi cahaya matahari bagi biota fotosintetik.

3. puluhan ton padatan terlarut yang dibuang hampir lebih dari 3 juta orang akan mengendap dan merubah karakteristik dasar sungai, akibatnya beberapa biota yang menetap didasar sungai akan tereleminasi atau bahkan punah(5).

Pencemaran limbah domestik umumnya mengandung beberapa bahan pencemar antara lain BOD-COD, amonia, fosfat, deterjen dan tinja.

\section{a. BOD (Biochemical Oxygen Demand)}

BOD adalah jumlah oksigen terlarut yang dibutuhkan oleh bakteri pengurai untuk menguraikan bahan pencemar organik dalam air. Makin besar konsentrasi BOD suatu perairan, menunjukkan konsentrasi bahan organik di dalam air yang juga tinggi.

\section{b. COD (Chemical Oxygen Demand)}

COD adalah banyaknya oksigen yang di butuhkan untuk mengoksidasi bahan-bahan organik secara kimia. Pengukuran COD dilakukan, karena dalam bahan organik sering ditemukan bahan-bahan yang tidak dapat terurai secara biologis dan hanya dapat diuraikan secara kimiawi. Secara umum, angka BOD yang tinggi, mengindikasikan semakin besar tingkat pencemaran yang terjadi ${ }^{6}$.

c. Amonia $\left(\mathrm{NH}_{3}\right)$ itu termasuk gas alkalin yang tidak berwarna, lebih ringan dari udara dan punya aroma khas yang menyengat. Biasanya senyawa ini didapati berupa gas dengan bau tajam yang khas. Amonia sendiri adalah senyawa kaustik dan dapat merusak kesehatan. Kontak dengan gas amonia berkonsentrasi tinggi dapat menyebabkan kerusakan paru-paru dan bahkan kematian(7).

\section{d. Fosfat}

Fosfat terdapat dalam jumlah yang signifikan pada efluen pengolahan air buangan domestik $^{(8)}$. Fosfat yang terdapat bebas di alam, terutama di air, dominan berada di dalam bentuk senyawa $\mathrm{PO}_{4-3}$ (phosphate). Komposisi dari input fosfat terdiri dari industri 7,3\%, derivasi deterjen $40 \%$, buangan manusia $44 \%$ dan pembersih rumah $6,7 \%{ }^{(9)}$. Hal ini menunjukkan bagaimana berbagai aktivitas masyarakat di era modern dan semakin besarnya jumlah populasi manusia menjadi penyumbang yang sangat besar bagi lepasnya fosfat ke lingkungan air.

\section{e. Deterjen}

Deterjen sangat berbahaya bagi lingkungan karena dari beberapa kajian menyebutkan bahwa deterjen memiliki kemampuan untuk melarutkan bahan bersifat karsinogen, misalnya Benzonpyrene, selain gangguan terhadap masalah kesehatan, kandungan deterjen dalam air minum akan menimbulkan bau dan rasa tidak enak. Deterjen umumnya tersusun atas lima jenis bahan penyusun (10). Antara lain :

1. Surfaktan yang merupakan senyawa Alkyl Bensen Sulfonat (ABS) yang berfungsi untuk mengangkat kotoran pakaian. ABS memiliki sifat tahan terhadap penguraian oleh mikroorganisme (non biodegradab). 
2. Senyawa fosfat, (bahan pengisi) yang mencegah menempelnya kembali kotoran pada bahan yang sedang dicuci. Senyawa fosfat digunakan oleh semua merk deterjen memberikan andil yang cukup besar terhadap terjadinya proses eutrofikasi yang menyebabkan Booming Alga (meledaknya populasi tanaman air)

3. Pemutih dan pewangi (bahan pembantu) zat pemutih umumnya terdiri dari zat natrium karbonat. Menurut hasil riset organisasi konsumen Malaysia (CAP), pemutih dapat menimbulkan kanker pada manusia. sedangkan untuk pewangi lebih banyak merugikan konsumen karena bahan ini membuat makin tingginya biaya produksi, sehingga harga jual produk semakin mahal. Padahal zat pewangi tidak ada kaitannya dengan kemampuan mencuci.

4. Bahan penimbul busa yang sebenarnya tidak diperlukan dalam proses pencucian dan tidak ada hubungan antara daya bersih dengan busa yang melimpah.

5. Fluorescent, berguna untuk membuat pakaian lebih cemerlang.

\section{f. Tinja}

Tinja merupakan bagian yang paling berbahaya dari limbah domestik adalah mikroorganisme patogen yang terkandung dalam tinja, karena dapat menularkan beragam penyakit bila masuk tubuh manusia dalam 1 gram tinja mengandung 1 milyar partikel virus infektif, yang mampu bertahan hidup selama beberapa minggu pada suhu dibawah 10 derajat Celcius. Terdapat 4 mikroorganisme patogen yang terkandung dalam tinja yaitu : virus, Protozoa, cacing dan bakteri yang umumnya diwakili oleh jenis Escherichia coli (E-coli).

Menurut catatan Badan Kesehatan Dunia (WHO) melaporkan bahwa air limbah domestik yang belum diolah memiliki kandungan virus sebesar 100.000 partikel virus infektif setiap liternya, lebih dari 120 jenis virus patogen yang terkandung dalam air seni dan tinja. Sebagian besar virus patogen ini tidak memberikan gejala yang jelas sehingga sulit dilacak penyebabnya.

Saat ini E-coli adalah mikroorganisme yang mengancam badan air sungai. Bakteri penghuni usus manusia dan hewan berdarah panas ini telah mengkontaminasi badan air sungai, setelah tinja memasuki badan air, E-coli akan mengkontaminasi perairan, bahkan pada kondisi tertentu E-coli dapat mengalahkan mekanisme pertahanan tubuh dan dapat tinggal di dalam pelvix ginjal dan hati ${ }^{(5)}$.

\section{USAHA PENCEGAHAN PENCEMARAN AIR LIMBAH DOMESTIK}

Kondisi pencemaran air limbah domestik yang ada saat ini sebenarnya sudah lama diketahui oleh pemerintah baik dari pusat maupun daerah, dengan diterbitkannya Peraturan Pemerintah (PP) Nomor 20 tahun 1990 dan PP Nomor 82 Tahun 2001 tentang Pengelolaan Air dan Pengendalian Pencemaran Air, dimana diwajibkan semua air limbah domestik harus diolah terlebih dahulu sebelum dibuang ke saluran umum.

Begitupun Keputusan Menteri Lingkungan Hidup Nomor 112 Tahun 2003 tentang Baku Mutu Air Limbah Domestik, dimana setiap penanggung jawab usaha dan atau kegiatan permukiman rumah makan, perkantoran, perniagaan dan apartemen wajib melakukan pengolahan air limbah domestik sehingga mutu air limbah domestik yang dibuang ke lingkungan tidak melampaui baku mutu air limbah domestik yang telah ditetapkan. Peraturan Gubernur Prov. DKI Jakarta Nomor 122 Tahun 2005 tentang Pengelolaan Air Limbah Domestik di DKI Jakarta, dimana salah satu ketentuannya adalah Pengelolaan Air Limbah Domestik adalah upaya memperbaiki kualitas air yang berasal dari dari kegiatan rumah tangga/perkantoran sehingga layak untuk dibuang ke saluran kota/drainase ${ }^{(11)}$.

Pada intinya semua peraturan tersebut mewajibkan setiap rumah tangga atau usaha/jasa/industri mengolah air limbah domestiknya sesuai baku mutu yang berlaku sebelum dibuang ke saluran umum. Selain memberlakukan peraturan daerah, usaha-usaha lainpun dilakukan seperti sosialisasi hak dan kewajiban masyarakat dalam pengelolaan air limbah domestik, seminar dan pelatihan serta pembuatan prototipe alat pengolah air limbah domestik skala individu maupun skala komunalpun telah dilakukan di beberapa wilayah Jakarta. Meskipun demikian sampai saat ini usaha-usaha tersebut telah dilaksanakan akan tetapi hasilnya belum efektif. Beberapa faktor penyebab belum efektifnya usaha diatas adalah faktor kesadaran masyarakat dan faktor penegakan hukum masih rendah.

\section{PEMBAHASAN KONDISI PENCEMARAN AIR LIMBAH DOMESTIK DKI JAKARTA}

Pembahasan dilakukan pada data hasil pemantauan di titik-titik pantau sepanjang sungai Ciliwung di wilayah DKI Jakarta, mulai dari titik 1 yang berada di Kelapa Dua, Srengseng Sawah sampai di pintu air Manggarai sungai terbagi dua yang menuju ke Banjir Kanal Barat (Titik 1, 2, 2A, $3,3 A, 4,5,5 A, 6$ ) berakhir di Muara Angke) yang menuju Gunung Sahari (1, 2, 2A, 3, 29, 29A, 30) 
dan berakhir di Marina Ancol, Jakarta Utara (Gambar 1 dan Tabel 1).

Tabel 1. Lokasi titik pantau di sepanjang sungai Ciliwung

\begin{tabular}{|c|l|c|}
\hline Titik Pantau & \multicolumn{1}{|c|}{ Lokasi Pemantauan } & Golongan \\
\hline 1 & $\begin{array}{l}\text { Kelapa Dua ( Serengseng } \\
\text { Sawah ) }\end{array}$ & B \\
\hline 2 & $\begin{array}{l}\text { Intake PAM Condet ( Kampung } \\
\text { Gedong ) }\end{array}$ & B \\
\hline 2 A & Jl. M.T. Haryono & B \\
\hline 3 & Sebelum Pintu Air Manggarai & B \\
\hline 3 A & Jl. Halimun ( Guntur ) & B \\
\hline 4 & $\begin{array}{l}\text { Jl. KH. Mas Mansyur ( Karet } \\
\text { Tengsin ) }\end{array}$ & B \\
\hline 5 & Jl. Gudang PLN, Kebon Melati & B \\
\hline $5 A$ & Jl. Teluk Gong & B \\
\hline 6 & Jemb. PIK ( Muara Angke ) & D \\
\hline 29 & Jl. Kwitang, Senen & D \\
\hline $29 A$ & Jl. Gajah. Mada ( Tangki ) & D \\
\hline 30 & Jl. Ancol Marina & D \\
\hline
\end{tabular}

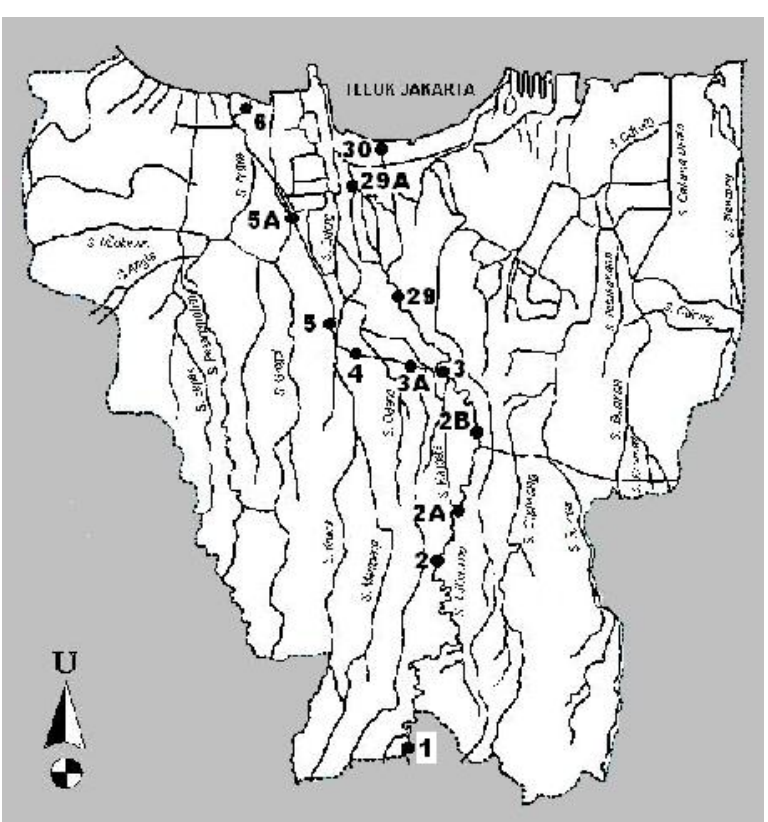

Gambar 1. Peta lokasi titik pantau di 13 sungai wilayah DKI Jakarta

Untuk mengetahui kondisi seberapa besar pencemaran air limbah domestik, maka beberapa paramater seperti organik (BOD/COD), amoniak, fosfat, deterjen dan bakteri coli yang akan dibahas dalam makalah ini.

Setelah dilakukan pengolahan dan analisa terhadap data pemantauan kualitas air sungai yang telah dilakukan BPLHD Prov. DKI Jakarta Tahun 1990 sampai $2008^{(12) \&(13)}$, menunjukkan terjadi peningkatan yang sangat signifikan setiap tahunnya pada parameter-parameter berikut dibawah ini.
Rata-rata konsentrasi amoniak mempunyai kecenderungan setiap tahun terus meningkat dan melewati baku mutu yang diperbolehkan, peningkatan mulai terjadi terutama di titik-titik pantau antara 3, 3A dan 29 (Gambar 2 dan 3), apabila lokasi-lokasi titik-titik tersebut (Manggarai, Menteng dan Senen) dibandingkan dengan populasi dan kepadatan penduduk di wilayah tersebut (Tabel 3), terlihat bahwa wilayah disekitar titik pantau tersebut mempunyai populasi dan kepadatan penduduk yang tinggi.

Rata-rata konsentrasi amoniak mempunyai kecenderungan setiap tahun terus meningkat dan melewati baku mutu yang diperbolehkan, peningkatan mulai terjadi terutama di titik-titik pantau antara 3, 3A dan 29 (Gambar 2 dan 3), apabila lokasi-lokasi titik-titik tersebut dibandingkan dengan populasi dan kepadatan penduduk di wilayah tersebut (Tabel 3), terlihat bahwa wilayah disekitar titik pantau tersebut mempunyai populasi dan kepadatan penduduk yang tinggi.

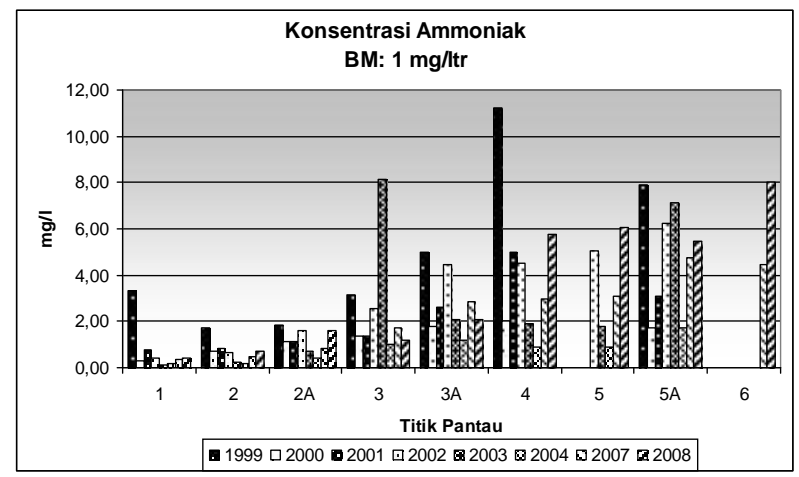

Gambar 2. Konsentrasi amonia di titik-titik pantau sepanjang sungai Ciliwung-Banjir Kanal barat.

Rata-rata konsentrasi amoniak mempunyai kecenderungan setiap tahun terus meningkat dan melewati baku mutu yang diperbolehkan, peningkatan mulai terjadi terutama di titik-titik pantau antara 3, 3A dan 29 (Gambar 2 dan 3), apabila lokasi-lokasi titik-titik tersebut dibandingkan dengan populasi dan kepadatan penduduk di wilayah tersebut (Tabel 3 ), terlihat bahwa wilayah disekitar titik pantau tersebut mempunyai populasi dan kepadatan penduduk yang tinggi.

Konsentrasi organik BOD dan COD di awal memasuki wilayah Jakarta sudah terlihat melewati baku mutu yang diperbolehkan untuk peruntukan air sungai Golongan B. Terjadi peningkatan konsentrasi $B O D$ tidak begitu signifikan dari tahun 1999 sampai 2004, akan tetapi pada tahun 2008 terjadi peningkatan begitu tajam (rata2 468\%) seperti terlihat pada Gambar 4 dan 5). Beban COD pada titik pantau 1 (Kelapa Dua, Depok) sudah terlihat cukup tinggi (melebihi baku mutu), hal ini menunjukkan bahwa sungai 
Ciliwung sudah tercemar saat memasuki wilayah Jakarta (Gambar 6 dan 7).

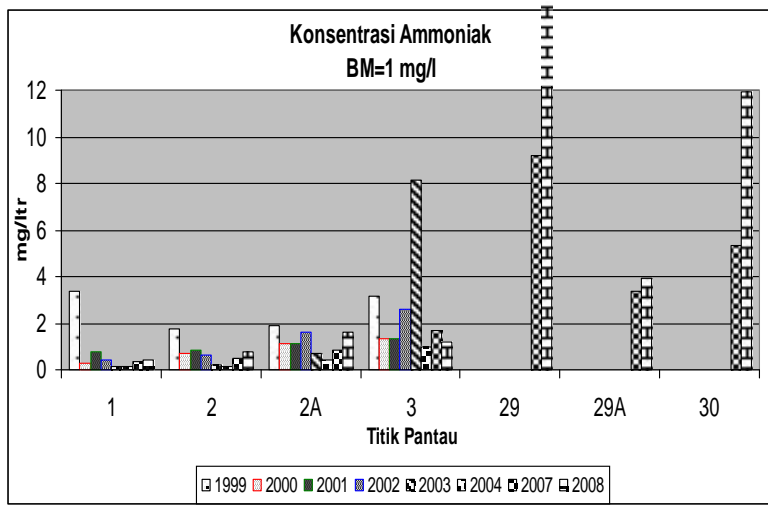

Gambar 3. Konsentrasi amonia di titik-titik pantau sepanjang sungai Ciliwung - Marina Ancol.

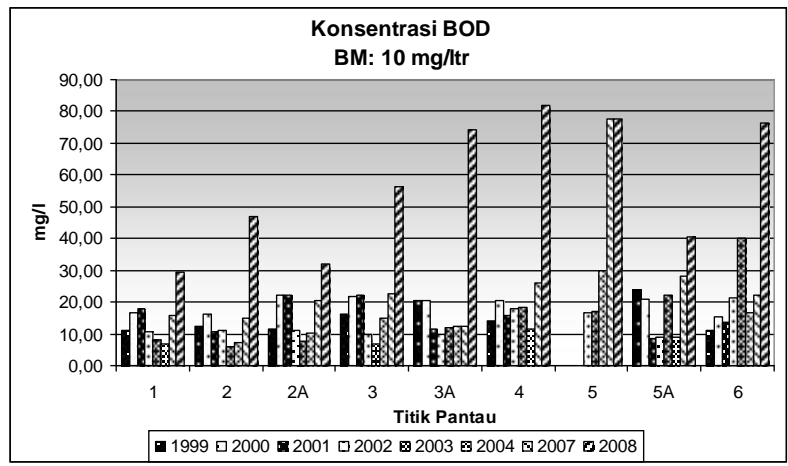

Gambar 4. Konsentrasi BOD di titik-titik pantau sepanjang sungai Ciliwung-Banjir Kanal barat.

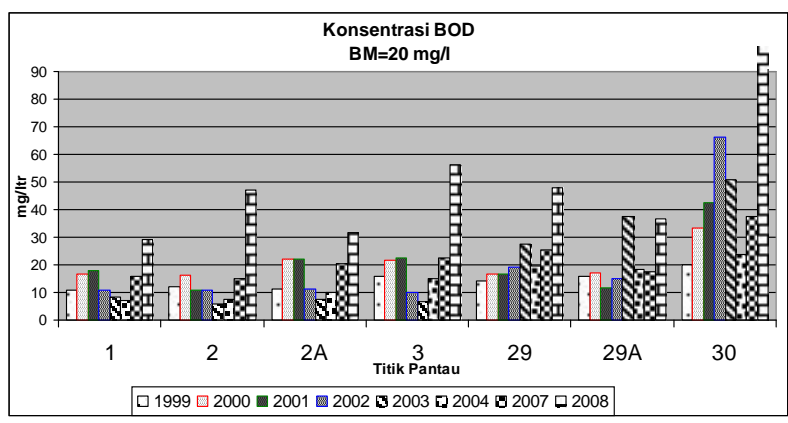

Gambar 5. Konsentrasi BOD di titik-titik pantau sepanjang sungai Ciliwung-Marina Ancol.

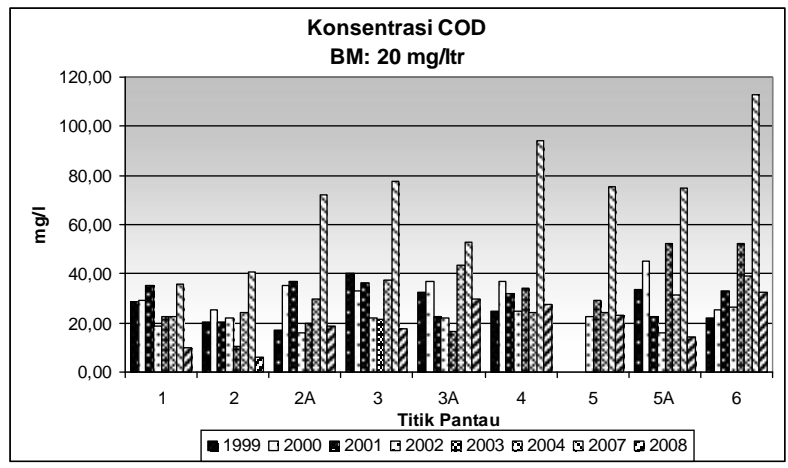

Gambar 6. Konsentrasi COD di titik-titik pantau sepanjang sungai Ciliwung-Banjir Kanal barat.

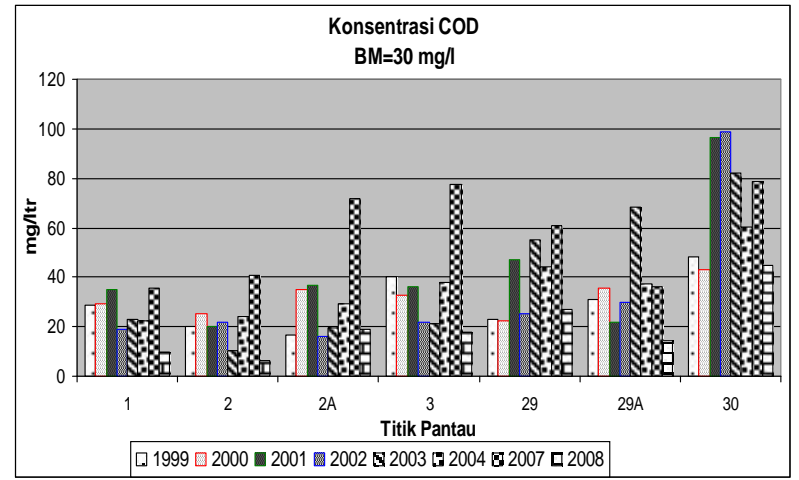

Gambar 7. Konsentrasi COD di titik-titik pantau sepanjang sungai Ciliwung-Marina Ancol.

Konsentrasi fosfat juga meningkat setiap tahun di sepanjang sungai Ciliwung menuju ke Marina Ancol, peningkatan ini terlihat sangat tinggi mulai dari titik-titik $3,3 \mathrm{~A}$ dan 4 (Karet Tengsin, Tanah Abang) Kecenderungan ini memperlihatkan buangan manusia sangat dominan mencemari sungai Ciliwung. Tahun 2003 menunjukkan tingkat pencemaran fosfat begitu tinggi (Gambar 8), apabila dilihat dari ratarata curah hujan tahunan di wilayah Jakarta maka tahun 2003 mempunyai curah hujan paling rendah (Tabel 4). Konsentrasi fosfat terlihat juga meningkat sangat tajam di sepanjang sungai Ciliwung ke Muara Angke yaitu di titik-titik 29, 29A dan 30, akibat beban buangan tidak hanya dari rumah tangga tetapi kontribusi buangan industri juga cukup besar (Gambar 9).

Peningkatan konsentrasi deterjen dari mulai masuk wilayah Jakarta Selatan hingga Jakarta Utara terjadi setiap tahun mulai dari tahun 1999 sampai tahun 2004 terus terjadi. Akan tetapi tahun 2007 dan 2008 terjadi penurunan konsentrasi deterjen dan nilainya rata-rata dibawah baku mutu. Konsentrasi deterjen pada tahun 2003 terjadi peningkatan yang tinggi, hal ini dimungkinkan pada tahun tersebut kondisi sungai sangat pekat karena nilai rata-rata curah hujan tahun 2003 sangat rendah (Gambar 10 dan 11).

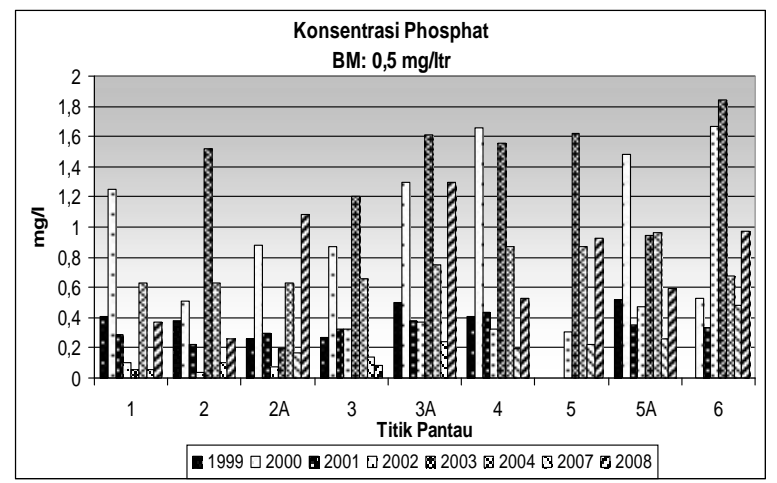

Gambar 8. Konsentrasi fosfat di titik-titik pantau sepanjang sungai Ciliwung-Muara Angke. 


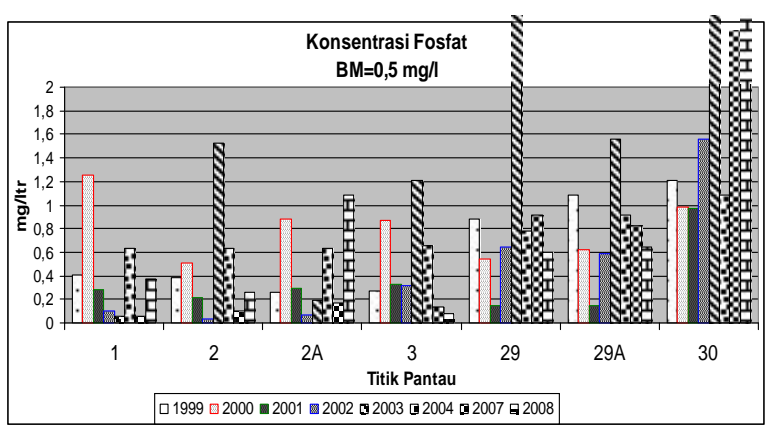

Gambar 9. Konsentrasi fosfat di titik-titik pantau sepanjang sungai Ciliwung-Marina Ancol.

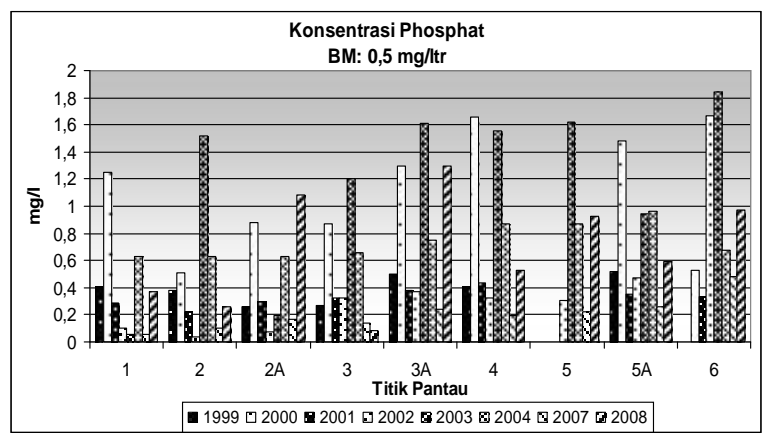

Gambar 10. Konsentrasi fosfat di titik-titik pantau sepanjang sungai Ciliwung-Muara Angke.

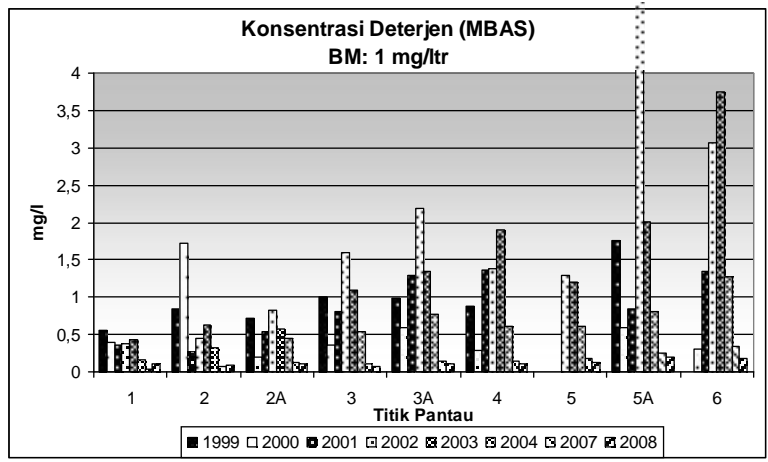

Gambar 10. Konsentrasi deterjen di titik pantau sepanjang sungai Ciliwung-Banjir Kanal barat.

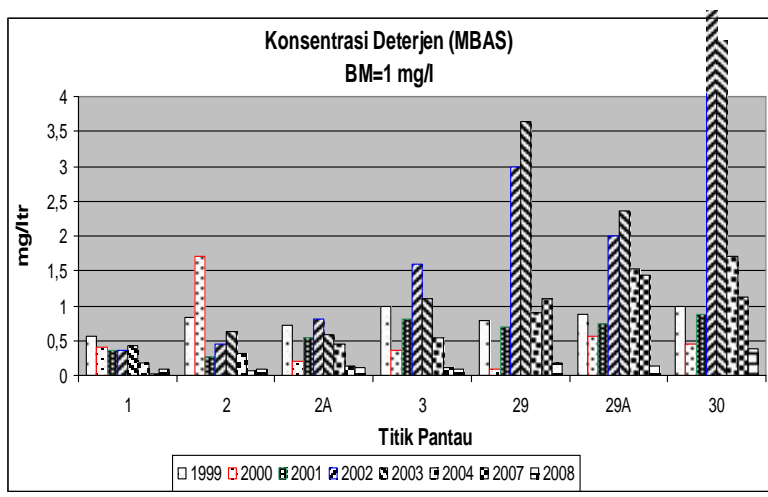

Gambar 11. Konsentrasi deterjen di titik pantau sepanjang sungai Ciliwung-Banjir-Marina Ancol.

Hasil pemantauan nilai bakteri Coli (E.Coli) menunjukkan bahwa peningkatan konsentrasi yang sangat tinggi terjadi mulai di titik $3,3 \mathrm{~A}$ dan
30 serta terus bertambah sampai ke teluk Jakarta, hal ini diperkirakan terjadi penambahan beban pencemar tidak hanya dari limbah rumah tangga tetapi juga limbah perkantoran dan limbah industri (Gambar 12 dan 13). Jumlah bakteri coli yang dibawa oleh tinja terlihat sangat tinggi, hal ini menunjukkan bahwa buangan dari rumah tangga langsung dibuang ke sungai Ciliwung tanpa melalui septik tank. Tentu saja sangat mungkin, tidak hanya buangan rumah tangga tetapi juga buangan perkantoran, rumah toko (ruko), dan lainnya juga turut andil dalam pencemaran sungai Ciliwung.

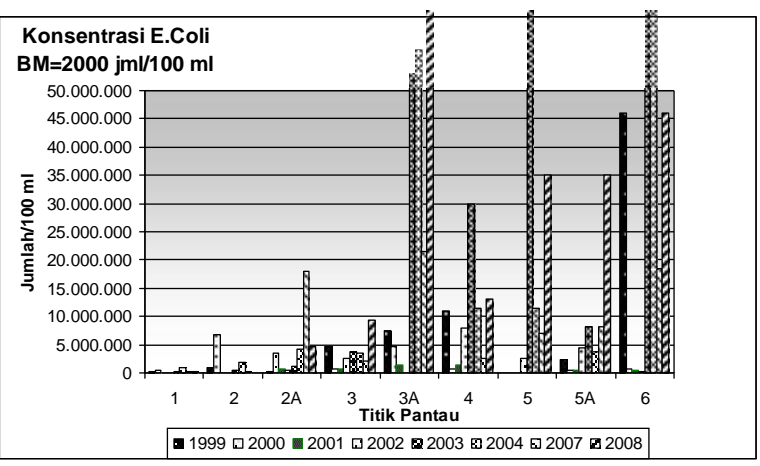

Gambar 12. Konsentrasi E. Coli di titik pantau sepanjang sungai Ciliwung-Banjir Kanal barat.

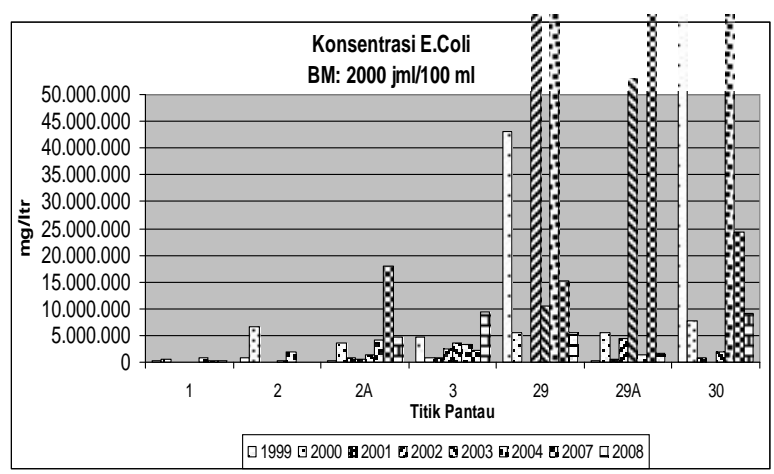

Gambar 13. Konsentrasi E. Coli di titik pantau sepanjang sungai Ciliwung-Marina Ancol.

BAKU MUTU LIMBAH CAIR DOMESTIK

\begin{tabular}{|ccc|c|}
\hline PARAMETER & SATUAN & $\begin{array}{c}\text { INDIVIDUAL / } \\
\text { RUMAH TANGGA }\end{array}$ & KOMUNAL \\
\hline $\mathrm{pH}$ & - & $6-9$ & $6-9$ \\
$\mathrm{KMnO}$ 1 & $\mathrm{Mg} / \mathrm{L}$ & 85 & 85 \\
\hline $\mathrm{TSS}$ & $\mathrm{Mg} / \mathrm{L}$ & 50 & 50 \\
\hline Amoniak & $\mathrm{Mg} / \mathrm{L}$ & 10 & 10 \\
Minyak \& Lemak & $\mathrm{Mg} / \mathrm{L}$ & 10 & 20 \\
\hline Senyawa Biru Metilen & $\mathrm{Mg} / \mathrm{L}$ & 2 & 2 \\
\hline $\mathrm{COD}$ & $\mathrm{Mg} / \mathrm{L}$ & 100 & 80 \\
$\mathrm{BOD}$ & $\mathrm{Mg} / \mathrm{L}$ & 75 & 50
\end{tabular}

Tabel 2. Baku Mutu Limbah Cair Domestik Berdasarkan Per.Gub DKI Jakarta No. 112 Tahun 2005 


\section{PENUTUP}

Hasil pembahasan diatas memperlihatkan bahwa kondisi pencemaran sungai Ciliwung di dominasi oleh pencemaran limbah domestik akibat tingginya konsentrasi parameterparamater BOD-COD, amonia, fosfat, deterjen dan bakteri coli.

Beban limbah domestik yang masuk ke Sungai Ciliwung sudah terlihat cukup tinggi di awal masuk wilayah Jakarta, hal ini mengindikasikan bahwa pencemaran terjadi tidak hanya di wilayah Jakarta tetapi juga di wilayah Depok atau Bogor. Meningkatnya perkembangan pembangunan perumahan disepanjang bantaran sungai Ciliwung dan maraknya pertokoan di sepadan sungai di wilayah Depok dan Bogor serta tidak berfungsinya penegakan hukum merupakan beberapa faktor yang menyebabkan kualitas sungai Ciliwung terus memburuk. Dibutuhkan upaya yang terintegrasi antar wilayah yang lebih serius dan cepat untuk mengatasi pencemaran ini jika tidak sungai sebagai salah satu sumber kehidupan dan penyeimbang lingkungan akan rusak.

Kecenderungan pencemaran ini terus meningkat setiap tahunnya, diperkirakan 5 tahun (2015) kedepan kondisi kualitas air sungai Ciliwung akan terus memburuk dan sudah tidak mungkin digunakan sebagai air baku air minum lagi.

Upaya-upaya pemerintah yang sudah direncanakan serta yang telah dikukuhkan dalam peraturan daerah semestinya segera dilaksanakan secara konsisten, seperti mempercepat pembangunan pengolahan air limbah di setiap zona (Gambar 8). Kewajiban membuat septik tank baik komunal atau individual yang memenuhi standar baku mutu air limbah domestik (Tabel 2) di pemukiman yang berada di sepanjang sungai Ciliwung. Salah satu alternatif teknologi pengolahan air limbah domestik untuk skala rumah tangga yang telah diuji kehandalannya adalah sistem biofilter anaerob-aerob tipe Biotreat-10(14). Kemudian untuk merelokasi pemukiman kumuh di bantaran sungai dan lainnya. Serta upaya meningkatkan pengawasan, peringatan dan melakukan penegakan hukum secara terus menerus kepada pengelola industri, perumahan dan perkantoran yang tidak mempunyai ijin pembuangan limbah cair (IPLC).

\section{DAFTAR PUSTAKA}

1. ......., Laporan Status Lingkungan Hidup Provinsi DKI Jakarta Tahun 2008, BPLHD Prov. DKI Jakarta, 2008.

2. Agoes Widjanarko, DirJen Cipta Karya Departemen PU, Dalam Diskusi Media Kelangkaan Air Baku, Tantangan Dalam Penyediaan Air Minum di Gedung Bappenas, 2007.

3. Litbang Kompas, Sampahmu Mencemari Ciliwungku, 2006.

4. Peraturan Gubernur Provinsi DKI Jakarta No. 122 Tahun 1995 tentang Pengelolaan Air Limbah Domestik di Prov. DKI Jakarta.

5. Fakhrizal, Mewaspadai Bahaya Limbah Domestik Di Kali Mas, Lembaga Kajian Ekologi dan Konservasi Lahan Basah, 2004.

6. Yudo. S, Kondisi Pencemaran Teluk Jakarta, Jurnal Hidrosfir Indonesia, BPPT, 2007.

7. Akilawati dan Wahyuni, Makalah Kesehatan Lingkungan Tentang Unsur Sulfat $\left(\mathrm{SO}_{4}\right)$, Sulfida (S-2), Fluorida (F), Amonia $\left(\mathrm{NH}_{3}\right)$, Program Studi IImu Keperawatan Stikes Surya Global Yogyakarta, 2009.

8. Morse et al, 1993, The Economic and Environment Impact of Phosphorus Removal from Wastewater in the European Community.

9. Dojlido, J.R. \& Best, G.A. (1993) Chemistry of Water and Water Pollution. England Ellis Horwood Limited.

10.Teror di Balik Deterjen. (http://www.sinarharapan.co.id/berita/0110/24/ ipt02.html).

11.P. Tambunan, Slide Peraturan Gubernur Provinsi DKI JakartaTentang Pengelolaan Air Limbah Domestik;(http://bplhd.jakarta.go.id/.../ PERGUB/...PERGUB\%20122\%202005/Dise minasi\%20Pergub\%20122thn2005-Jan.ppt).

12.BPLHD, Prov. DKI Jakarta, Data Kualitas Air Sungai Tahun 1999 s.d. 2004.

13.Data Kualitas Air Sungai Tahun 2007-2008, (http://bplhd.jakarta.go.id).

14. Idaman, Nusa, 2006, Pengelolaan Air Limbah Domestik di DKI Jakarta, Jurnal Air Indonesia, Vol. 2 No. 2, November 2006. 


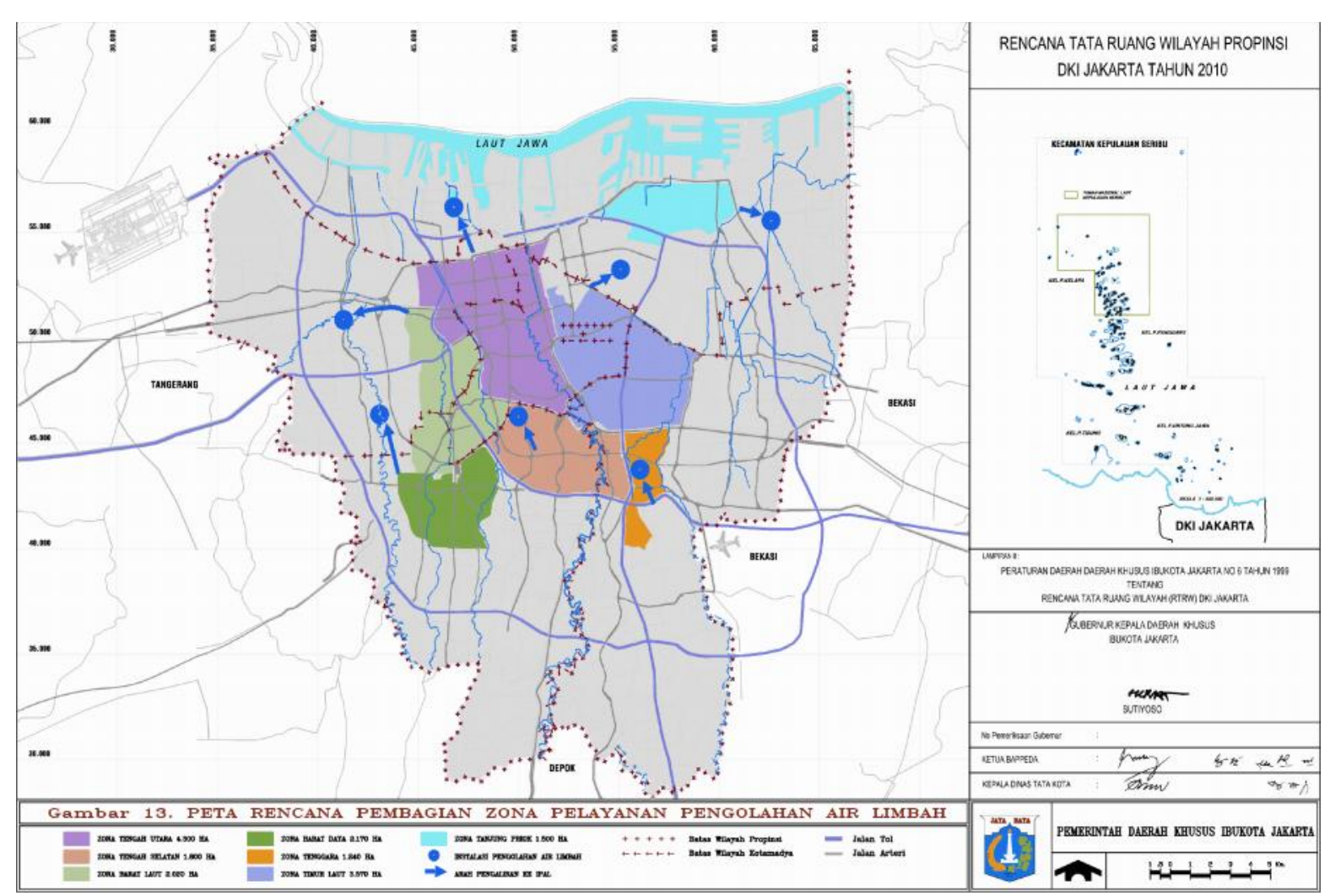

Sumber : BPLHD Provinsi DKI Jakarta

Gambar 16. Peta rencana pembagian zona pelayanan pengolahan air limbah

Tabel 3. Perkiraan Jumlah Penduduk Jakarta per Wilayah pada Tahun 2010

\begin{tabular}{|c|c|c|c|c|}
\hline NO. & WILAYAH & LUAS (HA) & POPULASI & KEPADATAN \\
\hline I. & JAKARTA PUSAT: & 4.935 & 1.730 .600 & 350,4 \\
\hline 1. & Gambir & 780 & 206.100 & 264,2 \\
\hline 2. & Sawah Besar & 622 & 212.300 & 341,3 \\
\hline 3. & Kemayoran & 821 & 313.000 & 381,2 \\
\hline 4. & Senen & 422 & 183.900 & 435,8 \\
\hline 5. & Cempaka Putih & 707 & 274.500 & 388,3 \\
\hline 6. & Menteng & 653 & 196.300 & 300,6 \\
\hline 7. & Tanah Abang & 930 & 344.500 & 370,4 \\
\hline II. & JAKARTA UTARA : & 13.943 & 376.700 & 94,9 \\
\hline 1. & Penjaringan & 4.539 & 499.700 & 110,1 \\
\hline 2. & Tanjung Priuk & 2.512 & 476.000 & 189,5 \\
\hline 3. & Koja & 2.922 & 550.400 & 188,4 \\
\hline 4. & Cilincing & 3.970 & 376.700 & 94,9 \\
\hline III. & JAKARTA BARAT : & 12.889 & 2.716 .600 & 210,8 \\
\hline 1. & Cengkareng & 5.749 & 616.600 & 107,3 \\
\hline 2. & Grogol Petamburan & 1.883 & 609.000 & 323,4 \\
\hline 3. & Taman Sari & 436 & 216.100 & 495,6 \\
\hline 4. & Tambora & 570 & 371.300 & 651,4 \\
\hline 5. & Kebon Jeruk & 4.251 & 903.600 & 212,6 \\
\hline
\end{tabular}




\begin{tabular}{|c|c|c|c|c|}
\hline IV. & JAKARTA SELATAN : & 14.616 & 3.157 .600 & 216,0 \\
\hline 1. & Tebet & 953 & 399.300 & 419,0 \\
\hline 2. & Setia Budi & 885 & 325.500 & 367,8 \\
\hline 3. & Mampang Prapatan & 1.584 & 401.400 & 253,4 \\
\hline 4. & Pasar Minggu & 4.822 & 542.000 & 112,4 \\
\hline 5. & Kebayoran Baru & 1.276 & 330.300 & 258,9 \\
\hline 6. & Kebayoran Lama & 3.278 & 915.400 & 279,3 \\
\hline 7. & Cilandak & 1.818 & 243.700 & 134,0 \\
\hline V. & JAKARTA TIMUR: & $18.765,97$ & 3.292 .400 & 175,4 \\
\hline 1. & Matraman & 485,67 & 284.300 & 585,4 \\
\hline 2. & Pulo Gadung & $1.571,15$ & 458.300 & 291,7 \\
\hline 3. & Jatinegara & $3.341,12$ & 973.800 & 291,5 \\
\hline 4. & Kramat Jati & $3.496,46$ & 569.900 & 163,0 \\
\hline 5. & Pasar Rebo & $5.623,49$ & 517.500 & 92,0 \\
\hline 6. & Cakung & $4.248,08$ & 488.600 & 115,0 \\
\hline & Total & $65.148,97$ & 12.800 .000 & 196,5 \\
\hline
\end{tabular}

Sumber : Kantor BPS Prop. DKI Jakarta

Tabel 4. Kondisi Rata-rata Iklim Jakarta Tahun 2004

\begin{tabular}{|c|c|c|c|c|}
\hline $\begin{array}{c}\text { Bulan } \\
\text { Month }\end{array}$ & $\begin{array}{c}\text { Curah Hujan } \\
\text { Rainfall } \\
\text { (MM) }\end{array}$ & $\begin{array}{c}\text { Tekanan Atmosfir } \\
\text { Atmospheric } \\
\text { Pressure } \\
\text { (MBS) }\end{array}$ & $\begin{array}{c}\text { Kelembaban } \\
\text { Humidity } \\
\text { (\%) }\end{array}$ & $\begin{array}{c}\text { Arah Angin } \\
\text { Wind } \\
\text { Direction } \\
\text { (Points) }\end{array}$ \\
\hline (1) & $\mathbf{( 2 )}$ & $\mathbf{( 3 )}$ & $\mathbf{( 4 )}$ & $\mathbf{( 5 )}$ \\
\hline Januari & 157,6 & $1.010,4$ & 83 & 360 \\
\hline Pebruari & 384,7 & $1.010,4$ & 81 & 90 \\
\hline Maret & 361,5 & $1.009,7$ & 80 & 270 \\
\hline April & 276,3 & $1.010,3$ & 82 & 45 \\
\hline Mei & 203,9 & $1.010,8$ & 81 & 90 \\
\hline Juni & 32,4 & $1.012,7$ & 76 & 90 \\
\hline Juli & 52,4 & $1.010,2$ & 73 & 90 \\
\hline Agustus & 0,0 & $1.014,4$ & 71 & 45 \\
\hline September & 5,4 & $1.012,6$ & 76 & 45 \\
\hline Oktober & 131,8 & $1.011,9$ & 78 & 360 \\
\hline Nopember & 176,5 & $1.011,8$ & 79 & 360 \\
\hline Desember & 323,0 & $1.010,0$ & 81 & 360 \\
\hline Rata-rata/ & 175,5 & $1.011,3$ & 78,4 & - \\
\hline Average & & & & $\mathbf{7 7 , 3}$ \\
\hline $\mathbf{2 0 0 3}$ & $\mathbf{1 1 3 . 8}$ & $\mathbf{1 . 0 1 0 , 8}$ & $\mathbf{7 7 , 3}$ & \\
\hline 2002 & 190.7 & $1.010,5$ & 76,4 & 107,5 \\
\hline 2001 & 133.3 & $1.009,7$ & 77,1 & 330,0 \\
\hline 2000 & 158.1 & $1.009,5$ & 78,1 & 212,1 \\
\hline 1999 & 162.4 & $1.009,6$ & 78,1 & 212,1 \\
\hline
\end{tabular}

Sumber : Kantor BPS Prop. DKI Jakarta 